\title{
Tepidiphilus margaritifer gen. nov., sp. nov., isolated from a thermophilic aerobic digester
}

Correspondence

Célia M. Manaia celman@esb.ucp.pt

\author{
Célia M. Manaia, ${ }^{1}$ Balbina Nogales ${ }^{2}$ and Olga C. Nunes ${ }^{3}$ \\ 1Escola Superior de Biotecnologia, Universidade Católica Portuguesa, 4200-072 Porto, \\ Portugal \\ ${ }^{2}$ Area de Microbiologia, Universitat de les Illes Balears, 07071 Palma de Mallorca, Spain \\ ${ }^{3}$ LEPAE-Departamento de Engenharia Química, Faculdade de Engenharia, Universidade do \\ Porto, 4200-465 Porto, Portugal
}

\begin{abstract}
A moderately thermophilic bacterium is described, strain $\mathrm{N} 2-214^{\top}$, that was isolated from an enrichment culture, growing on caprolactone, obtained from a sample from a water-treatment sludge aerobic digester operating at temperatures around $60^{\circ} \mathrm{C}$. The organism was aerobic, Gram-negative, oxidase- and catalase-positive, with a polar flagellum, and capable of growth at temperatures as high as $61^{\circ} \mathrm{C}$. The major fatty acids of strain $\mathrm{N} 2-214^{\top}$ were $\mathrm{C}_{16: 0,} \mathrm{C}_{18: 1}$ and cyclo- $\mathrm{C}_{19: 0}$. The phylogenetic relationships of the strain, derived from $16 \mathrm{~S}$ rRNA gene sequence comparisons, demonstrated it to be a member of the $\beta$-subclass of the Proteobacteria. The highest $16 \mathrm{~S}$ rDNA sequence similarity of isolate N2-214 ${ }^{\top}$ was to Azoarcus buckelii (91.9\%), Thauera aromatica (92\%) and Hydrogenophilus thermoluteolus (92.7\%). On the basis of phylogenetic analyses and physiological and chemotaxonomic characteristics, it is proposed that isolate $\mathrm{N} 2-214^{\top}\left(=\mathrm{DSM} 15129^{\top}=\mathrm{LMG} 21637^{\top}\right)$ represents a new genus and species,

Tepidiphilus margaritifer gen. nov., sp. nov.
\end{abstract}

\section{INTRODUCTION}

The vast majority of species belonging to the class Proteobacteria of the domain Bacteria are mesophilic; nevertheless, some slightly or extremely thermophilic genera and species have been described. Thermophilic organisms are distributed among the different subclasses of the Proteobacteria, and most of them are chemolithotrophs that can use $\mathrm{H}_{2}$ or sulfur/sulfur compounds as electron donors. Within the $\beta$-subclass of the Proteobacteria, eight species of thermophilic organisms, included in five genera, have been described to date. The species Thiomonas thermosulfata (Shooner et al., 1996), Thermothrix azorensis (Odintsova et al., 1996), Thermothrix thiopara (Caldwell et al., 1976) and Tepidimonas ignava (Moreira et al., 2000) represent thermophilic organisms, characterized by their ability to use sulfur or sulfur compounds as an energy source. Tepidimonas ignava, isolated from a Portuguese hot spring, is the only strictly heterotrophic organism among these sulfur bacteria. The genus Hydrogenophilus currently comprises two species, Hydrogenophilus thermoluteolus (Hayashi et al., 1999) and Hydrogenophilus hirschii (Stöhr et al., 2001),

Published online ahead of print on 7 February 2003 as DOI 10.1099/ ijs.0.02538-0.

Abbreviation: $\mathrm{PHB}$, poly- $\beta$-hydroxybutyrate.

The GenBank/EMBL/DDBJ accession number for the 16S rDNA sequence of isolate $\mathrm{N} 2-214^{\top}$ is AJ504663. both of which are hydrogen-oxidizing bacteria with the ability to fix $\mathrm{CO}_{2}$. Caldimonas manganoxidans, a chemoorganoheterotrophic, thermophilic member of the $\beta$ Proteobacteria, was described recently (Takeda et al., 2002).

Isolation of these organisms has frequently occurred under conditions favouring the recovery of specific metabolic types, namely hydrogen- and sulfur-oxidizing bacteria; this may explain why the majority of thermophilic members of the $\beta$-Proteobacteria described to date are chemolithotrophic. Indeed, it is intriguing that, despite the abundance of chemo-organoheterotrophic organisms belonging to the $\beta$-Proteobacteria, only a single thermophilic representative of this metabolic group has been described to date.

The present study describes a moderately thermophilic, chemo-organoheterotrophic bacterium, strain $\mathrm{N} 2-214^{\mathrm{T}}$, isolated from a thermophilic aerobic digester of watertreatment sludge. On the basis of $16 \mathrm{~S}$ rDNA-based phylogenetic analyses and physiological and chemotaxonomic characteristics, it is proposed that isolate $\mathrm{N} 2-214^{\mathrm{T}}$ represents a new genus and species, for which the name Tepidiphilus margaritifer gen. nov., sp. nov. is proposed.

\section{METHODS}

Isolation, cultivation conditions and bacterial strains. Strain $\mathrm{N} 2-214^{\mathrm{T}}$ was isolated from a caprolactone enrichment culture obtained from a thermophilic aerobic digester of a domestic 
wastewater-treatment plant in northern Portugal. In this treatment process, the decanted sludge is subjected to a mesobiotic anaerobic digestion followed by a thermophilic aerobic digestion, which reaches a maximal temperature of about $60^{\circ} \mathrm{C}$. The sample was transported, without temperature control, and used as an inoculum for enrichment on polycaprolactone diol polymer (Solvay) with a molecular mass of $1000 \mathrm{Da}$. The enrichment was carried out in mineral medium (medium A) (Manaia \& Moore, 2002) at $50{ }^{\circ} \mathrm{C}$. Strain $\mathrm{N} 2-214^{\mathrm{T}}$ was purified from the mixed culture obtained in this enrichment by subculturing on Luria-Bertani (LB) broth containing $20 \mathrm{~g}$ agar $^{-1}$ (LB agar) (Carlton \& Brown, 1981). The isolate was maintained on LB agar or cryo-preserved in LB broth containing $15 \%(\mathrm{v} / \mathrm{v})$ glycerol.

Determination of morphological, growth and biochemical characteristics. Colony and cell morphology, Gram-staining reaction, production of spores, accumulation of poly- $\beta$-hydroxybutyrate (PHB) granules, the number and position of flagella and the temperature range for growth were examined as described by Manaia et al. (2003).

Phenotypic tests were carried out as described by Smibert \& Krieg (1981), using 2-day cultures on LB agar. Unless otherwise stated, all incubations were performed at $50^{\circ} \mathrm{C}$. The $\mathrm{pH}$ tolerance range was examined in LB medium, using $10 \mathrm{mM}$ MES (Sigma), for $\mathrm{pH} 5 \cdot 0-6 \cdot 0$ or $10 \mathrm{mM}$ TAPS (Sigma) for $\mathrm{pH} 6 \cdot 0-9 \cdot 0$. Enzymic activities were tested using the API ZYM system by following the instructions of the manufacturer (bioMérieux). Hydrogenase activity was determined on the basis of the descriptions of Aragno \& Schlegel (1992) and Stöhr et al. (2001) as described by Manaia et al. (2003). The nutritional pattern was characterized using the API $50 \mathrm{CH}$ system and a defined medium (medium B) as described by Manaia et al. (2003). Chemolithoautotrophic growth, the use of $\mathrm{H}_{2}$ as an energy source and the ability to use sulfur or thiosulfate as electrons donors were tested as described by Manaia et al. (2003). The ability to grow in the absence of a source of combined nitrogen was tested using medium A without ammonium sulfate, under aerobic conditions or under an $\mathrm{N}_{2}$ atmosphere with nitrate as the electron acceptor.

Determination of genotypic characteristics. The DNA $\mathrm{G}+\mathrm{C}$ content was determined as described by Manaia et al. (2003).

165 rDNA sequence analysis. The $16 \mathrm{~S}$ rRNA gene sequence was determined after PCR amplification as described by Manaia et al. (2003). The nucleotide sequence was compared with reference $16 \mathrm{~S}$ rDNA sequences in the EMBL database using the FASTA program (Pearson \& Lipman, 1988) and subsequently aligned with reference sequences included in the ARB package (http://www.arb-home.de). Evolutionary distances derived from sequence-pair dissimilarities (Jukes \& Cantor, 1969) were calculated using the PHYLIP package (Felsenstein, 1989). Calculations were done by using a $50 \%$ conservation filter for the $\beta$-Proteobacteria implemented in the ARB package and by using a second filter that excluded only the most variable regions in the 16S rRNA molecule, which corresponded to inserts of different lengths amongst the reference sequences used in the analysis. The tree shown later is the one obtained using the second type of filter, since the topology of the tree for the most closely related genera did not vary regardless of which filter was used, and the bootstrap values were slightly higher. Ambiguously determined nucleotide positions or positions for which no sequence data were available in any of the reference sequences were excluded from the calculations.

Determination of chemotaxonomic characteristics. Polar lipids, methylated fatty acids and respiratory quinones were extracted and separated as described previously (Manaia et al., 2003).

\section{RESULTS AND DISCUSSION}

Cultivation at $50{ }^{\circ} \mathrm{C}$ in mineral medium supplemented with a polycaprolactone diol was used to enrich moderate thermophiles capable of using synthetic polymers as the sole source of carbon and energy. The inoculum for this enrichment was taken from a thermophilic aerobic digester of sludge from a domestic wastewater-treatment plant. The enrichment procedure resulted in a mixed culture, predominantly composed by Gram-positive rods, which, on the basis of phenotypic characterization, were identified as members of the genus Bacillus. Isolate $\mathrm{N} 2-214^{\mathrm{T}}$ was obtained through purification of cultivable organisms present in the mixed culture. In pure culture, this isolate was unable to grow in mineral medium supplemented with caprolactones, although good growth was observed when acetate was the only carbon source. At the optimal temperature for growth $\left(50^{\circ} \mathrm{C}\right)$, the doubling time in $\mathrm{LB}$ medium was approximately $1 \mathrm{~h}$. When cultured on LB agar, strain $\mathrm{N} 2-214^{\mathrm{T}}$ produced brilliant non-pigmented colonies, 1-2 $\mathrm{mm}$ in diameter, after $36-48 \mathrm{~h}$ growth. Under a strong light source, these colonies had a nacre-like appearance.

Cells of strain $\mathrm{N} 2-214^{\mathrm{T}}$ were Gram-negative, non-sporeforming rods, $2 \cdot 0 \mu \mathrm{m}$ long and $0.7 \mu \mathrm{m}$ wide, with a single polar flagellum. The isolate tested positive for oxidase and catalase and for the presence of intracellular PHB granules. Strain N2-214 ${ }^{\mathrm{T}}$ reduced nitrate to a compound more reduced than nitrite, since nitrite was not detected in the supernatant of cultures. The isolate could grow under anaerobic conditions $\left(\mathrm{N}_{2}\right.$-saturated atmosphere) using nitrate as an electron acceptor, both in complex media and in mineral medium supplemented with acetate, ethanol or benzoate. Isolate $\mathrm{N} 2-214^{\mathrm{T}}$ could reduce triphenyltetrazolium in the presence of hydrogen but not in its absence, suggesting the presence of hydrogenase activity. However, since this organism could grow in a $\mathrm{N}_{2}$-saturated atmosphere in the absence of $\mathrm{H}_{2}$ gas, it is possible to conclude that this organism is not a strictly hydrogen-oxidizing chemolithoheterotroph. The optimal temperature for growth of strain $\mathrm{N} 2-214^{\mathrm{T}}$ in $\mathrm{LB}$ medium was around $50{ }^{\circ} \mathrm{C}$, with a maximal growth temperature of $61{ }^{\circ} \mathrm{C}$. The nutritional pattern of strain $\mathrm{N} 2-214^{\mathrm{T}}$ revealed an inability to use the sugars that were tested and a preference for organic acids, e.g. malate, acetate or benzoate, as carbon sources; other substrates, such as ethanol and the amino acids glutamic acid and asparagine, could also be used as single carbon sources (Table 1). The strain could not grow autotrophically in mineral medium supplemented with sodium hydrogen carbonate in the presence of hydrogen, $S^{0}$ or thiosulfate; in the presence of acetate as a carbon source, these potential electron donors did not enhance growth.

The inability of isolate $\mathrm{N} 2-214^{\mathrm{T}}$ to fix nitrogen or assimilate nitrate was evidenced by the fact that this organism could not grow in mineral medium without combined nitrogen under aerobic conditions, or in the same medium supplemented with nitrate under a $\mathrm{N}_{2}$ atmosphere. 
Table 1. Phenotypic characteristics of isolate $\mathrm{N} 2-214^{\mathrm{T}}$

Strain N2-214 ${ }^{\mathrm{T}}$ was unable to use the following compounds as sole sources of carbon: glycerol, erythritol, $\mathrm{D}$-arabinose, L-arabinose, ribose, D-xylose, L-xylose, adonitol, methyl $\beta$-xyloside, galactose, D-glucose, D-fructose, D-mannose, L-sorbose, rhamnose, dulcitol, inositol, mannitol, sorbitol, methyl $\alpha$-D-mannoside, methyl $\alpha$-D-glucoside, $N$-acetylglucosamine, amygdalin, arbutin, salicin, cellobiose, maltose, lactose, melibiose, sucrose, trehalose, inulin, melezitose, D-raffinose, starch, glycogen, xylitol, $\beta$-gentiobiose, D-turanose, D-lyxose, D-tagatose, D-fucose, L-fucose, D-arabitol, L-arabitol, gluconate, 2-ketogluconate, 5-ketogluconate, hydroxyproline, L-alanine, L-serine, L-glycine, L-histidine, DL-methionine, L-arginine, toluene and polycaprolactone (molecular mass 1000 and above). Strain $\mathrm{N} 2-214^{\mathrm{T}}$ was unable to grow autotrophically with $\mathrm{H}_{2}, \mathrm{~S}^{0}$ or $\mathrm{S}_{2} \mathrm{O}_{3}^{2-}$, did not fix nitrogen and did not grow in the presence of ampicillin $(10 \mu \mathrm{g})$, penicillin $\mathrm{G}(10 \mathrm{U})$ or $3 \% \mathrm{NaCl}$ or at $\mathrm{pH} 5$ or 9 . Strain $\mathrm{N} 2-214^{\mathrm{T}}$ did not require growth factors (vitamins or amino acids). The following enzymes were absent from isolate $\mathrm{N} 2-214^{\mathrm{T}}$ : cystine arylamidase, trypsin, $\alpha$-chymotrypsin, $\alpha$-galactosidase, $\beta$-galactosidase, $\beta$-glucuronidase, $\alpha$-glucosidase, $N$-acetyl- $\beta$-glucosaminidase, $\alpha$-fucosidase, $\alpha$-mannosidase, tweenase (Tween 80 ), amylase and gelatinase.

\begin{tabular}{|lclc|}
\hline Characteristic & Response & Characteristic & Response \\
\hline Presence of: & & Anaerobic growth with nitrate & + \\
Motility/polar flagellum & + & Hydrogenase activity & + \\
Catalase & + & Growth in presence of/at: & \\
Cytochrome-c oxidase & + & Nalidixic acid $(30 \mu \mathrm{g})$ & + \\
PHB & + & $3 \%$ NaCl & + \\
Utilization as carbon source: & & pH 6 and 8 & \\
Acetate & + & Activity of enzymes: & + \\
Malate & + & Alkaline phosphatase & + \\
Caproate & + & Esterase $\left(\mathrm{C}_{4}\right)$ & + \\
Benzoate & + & Esterase lipase $\left(\mathrm{C}_{8}\right)$ & + \\
Phenylacetate & + & Lipase $\left(\mathrm{C}_{14}\right)$ & + \\
Ethanol & + & Leucine arylamidase & + \\
Proline & + & Valine arylamidase & + \\
L-Asparagine & + & Acid phosphatase & + \\
L-Glutamic acid & + & Naphthol-AS-BI-phosphohydrolase & + \\
Reduction of nitrate & + & $\beta$-Glucosidase & + \\
\hline
\end{tabular}

The $\mathrm{G}+\mathrm{C}$ content of the genomic DNA of strain $\mathrm{N} 2-214^{\mathrm{T}}$ was $64 \cdot 8 \mathrm{~mol} \%$.

Nearly the complete $16 \mathrm{~S}$ rDNA sequence of strain N2-214 was determined (1456 nucleotides). Phylogenetic analysis of the $16 \mathrm{~S}$ rDNA sequence of strain $\mathrm{N} 2-214^{\mathrm{T}}$ showed its affiliation to the $\beta$-Proteobacteria, a result that is in agreement with the polar lipid and respiratory quinone composition (see below). The 16S rDNA sequence was then compared with all species with validly published names of the most closely related genera, Azoarcus, Thauera and Hydrogenophilus (Springer et al., 1998; Hayashi et al., 1999; Song et al., 1998, 1999, 2000, 2001; Reinhold-Hurek \& Hurek, 2000; Stöhr et al., 2001; Mechichi et al., 2002), and several other genera in the $\beta$-Proteobacteria. The 16S rDNA sequence of strain $\mathrm{N} 2-214^{\mathrm{T}}$ was not closely related to those of other genera within this subclass, the highest similarities (approx. 92-93\%) being to the sequences of Azoarcus buckelii (Mechichi et al., 2002), Thauera aromatica (Anders et al., 1995) and H. thermoluteolus (Hayashi et al., 1999). Comparative evolutionary distance analyses of the $16 \mathrm{~S}$ rDNA sequence of strain $\mathrm{N} 2-214^{\mathrm{T}}$ demonstrated that it branched from the lineage leading to the genus Hydrogenophilus
(Fig. 1), a result that was also supported by parsimony, maximum-likelihood and bootstrapping methods. The polar lipid pattern of strain N2-214 $4^{\mathrm{T}}$, obtained by TLC, revealed the presence of phosphatidylethanolamine (PE) and phosphatidylglycerol (PG) as the major phospholipids. A similar polar lipid pattern, characterized by the predominance of PE and PG, is described for other members of the $\beta$-Proteobacteria (Wilkinson, 1988). The only respiratory quinone detected for isolate $\mathrm{N} 2-214^{\mathrm{T}}$ was ubiquinone 8 , which is also characteristic of micro-organisms belonging to the $\beta$-Proteobacteria (Suzuki et al., 1993).

The fatty acid composition of strain $\mathrm{N} 2-214^{\mathrm{T}}$ was analysed using LB agar cultures grown at $50^{\circ} \mathrm{C}$. Under these conditions, the methyl esters of fatty acids $\mathrm{C}_{16: 0}$ and cyclo- $\mathrm{C}_{19: 0}$ were predominant, followed by the unsaturated fatty acid $\mathrm{C}_{18: 1}$. These components constituted more than $75 \%$ of the total fatty acids (Table 2). A lower growth temperature $\left(30^{\circ} \mathrm{C}\right)$ promoted a dramatic shift between the content of the unsaturated fatty acids $\mathrm{C}_{18: 1}$ and $\mathrm{C}_{16: 1}$, which doubled, and that of cyclo- $\mathrm{C}_{19: 0}$, which, under these conditions, represented only $3 \%$ of total fatty acids (results not shown). The hydroxy fatty acid 3-OH C $10: 0$ was also detected, and its 


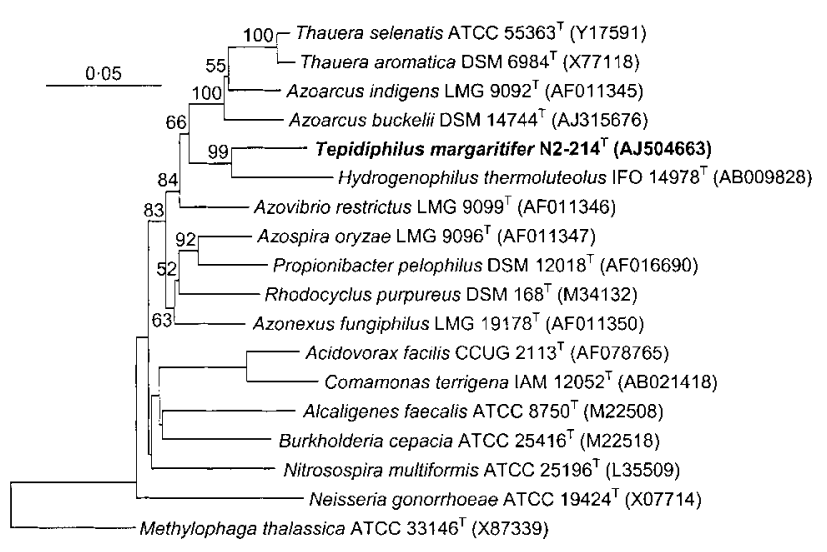

Fig. 1. Phylogenetic relationships based on 16S rDNA sequences between strain $\mathrm{N} 2-214^{\top}$ and representatives of related genera within the $\beta$-Proteobacteria. The dendrogram was generated from evolutionary distances, calculated from pairwise dissimilarities, using the FITCH program from the PHYLIP package. Accession numbers are given in parentheses. Bootstrap values for branches leading to the sequence of N2$214^{\top}$ and its closest relatives, obtained after 1000 resamplings, are shown in the tree. The sequence of Methylophaga thalassica ATCC $33146^{\top}$ was used as outgroup.

level was not temperature-dependent. Characteristics that distinguish isolate $\mathrm{N} 2-214^{\mathrm{T}}$ from the type strains of the type species of genera with the closest $16 \mathrm{~S}$ rRNA similarity to the proposed new genus are shown in Table 3.

To date, few thermophilic organisms have been described in the $\beta$-Proteobacteria. However, this may be due to the
Table 2. Mean fatty acid composition of strain $N 2-214^{\top}$

Values are percentages of total fatty acids. Cells were grown on LB agar at $50{ }^{\circ} \mathrm{C}$. Components that made up less than $1 \%$ of the total are summed as 'Other' and included iso- $\mathrm{C}_{11: 0} 3-\mathrm{OH}, \mathrm{C}_{12: 0}$, $\mathrm{C}_{15: 0}, \mathrm{C}_{17: 0}, \mathrm{C}_{19: 1} \omega 12 t$ and $\mathrm{C}_{20: 1} \omega 9 t$.

\begin{tabular}{|lc|}
\hline Fatty acid & Content (\%) \\
\hline $\mathrm{C}_{10: 0} 3-\mathrm{OH}$ & $1 \cdot 4$ \\
$\mathrm{C}_{14: 0}$ & $2 \cdot 7$ \\
Summed feature $4^{\star}$ & $3 \cdot 7$ \\
$\mathrm{C}_{16: 0}$ & $36 \cdot 8$ \\
cyclo-C ${ }_{17: 0}$ & $6 \cdot 2$ \\
$\mathrm{C}_{16: 0} 3-\mathrm{OH}$ & $2 \cdot 9$ \\
Summed feature $7^{\star}$ & $15 \cdot 6$ \\
$\mathrm{C}_{18: 0}$ & $1 \cdot 6$ \\
cyclo-C & $25 \cdot 9$ \\
Other & $3 \cdot 2$ \\
\hline
\end{tabular}

${ }^{\star}$ Summed features contain one or more of the following: feature 4, $\mathrm{C}_{16: 1} \omega 7 c$ and/or iso- $\mathrm{C}_{15} 2-\mathrm{OH}$; feature $7, \mathrm{C}_{18: 1} \omega 7 c, \omega 9 t$ and/or $\omega 12 t$.

difficulty in cultivating these organisms under laboratory conditions, since bacteria belonging to the $\beta$-Proteobacteria have been detected in studies employing cultureindependent molecular methods to describe the biological diversity of high-temperature natural (e.g. Ward et al., 1998; Hugenholtz et al., 1998) and man-made environments (e.g. LaPara et al., 2000). The work of LaPara et al. (2000), describing the phylogenetic diversity of bacterial communities in thermophilic and mesophilic bioreactors used to

Table 3. Characteristics of isolate $\mathrm{N} 2-214^{\top}$ and related type strains

Strains: 1, Thauera selenatis $\mathrm{AX}^{\mathrm{T}}$ (data from Macy et al., 1993; Song et al., 2000); 2, Azoarcus indigens VB32 ${ }^{\mathrm{T}}$ (Reinhold-Hurek et al., 1993); 3, Hydrogenophilus thermoluteolus $\mathrm{TH}^{-{ }^{\mathrm{T}}}$ (Goto et al., 1978; Hayashi et al., 1999; Stöhr et al., 2001); 4, N2-214 ${ }^{\mathrm{T}}$. NA, Data not available. All strains utilize acetate.

\begin{tabular}{|c|c|c|c|c|}
\hline Characteristic & 1 & 2 & 3 & 4 \\
\hline Optimal temperature for growth $\left({ }^{\circ} \mathrm{C}\right)$ & $25-30$ & 28 & $50-52$ & 50 \\
\hline Hydrogenase activity & NA & NA & + & + \\
\hline Anaerobic growth with nitrate & - & - & - & + \\
\hline $\mathrm{N}_{2}$ used as nitrogen source & NA & + & - & - \\
\hline \multicolumn{5}{|l|}{ Utilization of carbon source: } \\
\hline Glucose & + & - & - & - \\
\hline Glutamate & + & + & NA & + \\
\hline Asparagine & + & - & NA & + \\
\hline Benzoate & + & - & - & + \\
\hline
\end{tabular}


treat pharmaceutical wastewater, refers to the presence of clones that have the closest phylogenetic affiliation to the $\beta$-proteobacterium HMD 444 (accession number AB015328) in both meso- and thermophilic bioreactors. In this respect, is interesting to note that strains HMD 444 and N2-214 ${ }^{\mathrm{T}}$ share $16 \mathrm{~S}$ rRNA sequence identity above $99 \%$ (according to FASTA analysis), suggesting that they might eventually represent the same species. However, such a conclusion would only be possible on the basis of a DNA-DNA hybridization study (Stackebrandt \& Goebel, 1994).

\section{Description of Tepidiphilus gen. nov.}

Tepidiphilus (Te.pi.di'phi.lus. L. adj. tepidus lukewarm; Gr. adj. philos friendly to; N.L. masc. n. Tepidiphilus liker of lukewarm conditions).

Forms rod-shaped cells that stain Gram-negative. Endospores are not formed. Slightly thermophilic. PHB granules are accumulated. Grows anaerobically in the presence of nitrate. Oxidase- and catalase-positive. Major phospholipids are PE and PG; ubiquinone 8 is the major respiratory quinone. Major fatty acids are $\mathrm{C}_{16: 0}$ and cyclo- $\mathrm{C}_{19: 0}$. Chemo-organotrophic. Organic acids and amino acids, but no sugars, are used as single carbon sources. The type species is Tepidiphilus margaritifer.

\section{Description of Tepidiphilus margaritifer sp. nov.}

Tepidiphilus margaritifer (mar.ga.ri'ti.fer. L. n. margarita pearl; L. masc. suffix -fer carrying; N.L. masc. adj. margaritifer pearl-carrying, referring to the nacre-like appearance of the colonies).

Shows the following properties in addition to those in the genus description. Forms rod-shaped cells, $2.0 \mu \mathrm{m}$ long and $0.7 \mu \mathrm{m}$ wide. Cells are motile by a single polar flagellum. Colonies grown on LB agar are nacre-like and 1-2 $\mathrm{mm}$ in diameter after $36-48 \mathrm{~h}$ growth. Growth occurs above $25^{\circ} \mathrm{C}$ and below $61{ }^{\circ} \mathrm{C}$; the optimal growth temperature is approximately $50^{\circ} \mathrm{C}$. Growth occurs between pH 6 and 8. Hydrogenase-positive. The major fatty acids at the optimal temperature for growth are $\mathrm{C}_{16: 0}, \mathrm{C}_{18: 1}$ and cyclo- $\mathrm{C}_{19: 0} ; \mathrm{C}_{10: 0} 3-\mathrm{OH}$ is also present. The DNA G+C content of the type strain is $64 \cdot 8 \mathrm{~mol} \%$.

The type strain, strain $\mathrm{N} 2-214^{\mathrm{T}} \quad\left(=\mathrm{DSM} \quad 15129^{\mathrm{T}}=\right.$ LMG $21637^{\mathrm{T}}$ ), was isolated from a thermophilic digester of wastewater-treatment sludge.

\section{ACKNOWLEDGEMENTS}

C. M. M. thanks Nuno Cerca and Nuno Marcos (Escola Superior de Biotecnologia) for their collaboration on the preparation of the enrichment cultures and Fernanda Nobre (Departamento de Zoologia da Universidade de Coimbra) for fatty acid methyl ester analyses. The authors thank Solvay for the caprolactones and ETAR de Parada for the sampling.

\section{REFERENCES}

Anders, H.-J., Kaetzke, A., Kämpfer, P., Ludwig, W. \& Fuchs, G. (1995). Taxonomic position of aromatic-degrading denitrifying pseudomonad strains $\mathrm{K} 172$ and KB 740 and their description as new members of the genera Thauera, as Thauera aromatica sp. nov., and Azoarcus, as Azoarcus evansii sp. nov., respectively, members of the beta subclass of the Proteobacteria. Int J Syst Bacteriol 45, 327-333.

Aragno, M. \& Schlegel, H. G. (1992). The mesophilic hydrogen oxidizing (Knallgas) bacteria. In The Prokaryotes, 2nd edn, pp. 3917-3933. Edited by A. Balows, H. G. Trüper, M. Dworkin, W. Harder \& K. H. Schleifer. New York: Springer.

Caldwell, D. E., Caldwell, S. J. \& Laycock, J. P. (1976). Thermothrix thiopara gen. et sp. nov. a facultatively anaerobic facultative chemolithotroph living at neutral $\mathrm{pH}$ and high temperature. Can J Microbiol 22, 1509-1517.

Carlton, B. C. \& Brown, B. J. (1981). Gene mutation. In Manual Methods for General Microbiology, pp. 409-443. Edited by P. Gerhardt, R. G. E. Murray, R. N. Costilow, E. W. Nester, W. A. Wood, N. R. Krieg \& G. H. Phillips. Washington, DC: American Society for Microbiology.

Felsenstein, J. (1989). PHYLIP - phylogeny inference package. Cladistics 5, 164-166.

Goto, E., Kodama, T. \& Minoda, Y. (1978). Growth and taxonomy of thermophilic hydrogen bacteria. Agr Biol Chem 42, 1305-1308.

Hayashi, N. R., Ishida, T., Yokota, A., Kodama, T. \& Igarashi, Y. (1999). Hydrogenophilus thermoluteolus gen. nov., sp. nov., a thermophilic, facultatively chemolithoautotrophic, hydrogen-oxidizing bacterium. Int J Syst Bacteriol 49, 783-786.

Hugenholtz, P., Pitulle, C., Hershberger, K. L. \& Pace, N. R. (1998). Novel division level bacterial diversity in a Yellowstone hot spring. J Bacteriol 180, 366-376.

Jukes, T. H. \& Cantor, C. R. (1969). Evolution of protein molecules. In Mammalian Protein Metabolism, pp. 21-132. Edited by H. N. Munro. New York: Academic Press.

LaPara, T. M., Nakatsu, C. H., Pantea, L. \& Alleman, J. E. (2000). Phylogenetic analysis of bacterial communities in mesophilic and thermophilic bioreactors treating pharmaceutical wastewater. Appl Environ Microbiol 66, 3951-3959.

Macy, J. M., Rech, S., Auling, G., Dorsch, M., Stackebrandt, E. \& Sly, L. I. (1993). Thauera selenatis gen. nov., sp. nov., a member of the beta subclass of Proteobacteria with a novel type of anaerobic respiration. Int J Syst Bacteriol 43, 135-142.

Manaia, C. M. \& Moore, E. R. B. (2002). Pseudomonas thermotolerans sp. nov., a thermotolerant species of the genus Pseudomonas sensu stricto. Int J Syst Evol Microbiol 52, 2203-2209.

Manaia, C. M., Nunes, O. C. \& Nogales, B. (2003). Caenibacterium thermophilum gen. nov., sp. nov., isolated from a thermophilic aerobic digester of municipal sludge. Int J Syst Evol Microbiol 53, 1375-1382.

Mechichi, T., Stackebrandt, E., Gad'on, N. \& Fuchs, G. (2002). Phylogenetic and metabolic diversity of bacteria degrading aromatic compounds under denitrifying conditions, and description of Thauera phenylacetica sp. nov., Thauera aminoaromatica sp. nov., and Azoarcus buckelii sp. nov. Arch Microbiol 178, 26-35.

Moreira, C., Rainey, F. A., Nobre, M. F., da Silva, M. T. \& da Costa, M. S. (2000). Tepidimonas ignava gen. nov., sp. nov., a new chemolithoheterotrophic and slightly thermophilic member of the $\beta$-Proteobacteria. Int J Syst Evol Microbiol 50, 735-742.

Odintsova, E. V., Jannasch, H. W., Mamone, J. A. \& Langworthy, T. A. (1996). Thermothrix azorensis sp. nov., an obligately chemolithoautotrophic, sulfur-oxidizing, thermophilic bacterium. Int J Syst Bacteriol 46, 422-428. 
Pearson, W. R. \& Lipman, D. J. (1988). Improved tools for biological sequence comparison. Proc Natl Acad Sci U S A 85, 2444-2448.

Reinhold-Hurek, B. \& Hurek, T. (2000). Reassessment of the taxonomic structure of the diazotrophic genus Azoarcus sensu lato and description of three new genera and new species, Azovibrio restrictus gen. nov., sp. nov., Azospira oryzae gen. nov., sp. nov. and Azonexus fungiphilus gen. nov., sp. nov. Int J Syst Evol Microbiol 50, 649-659.

Reinhold-Hurek, B., Hurek, T., Gillis, M., Hoste, B., Vancanneyt, M., Kersters, K. \& De Ley, J. (1993). Azoarcus gen. nov., nitrogen-fixing proteobacteria associated with roots of Kallar grass (Leptochloa fusca (L.) Kunth), and description of two species, Azoarcus indigens sp. nov. and Azoarcus communis sp. nov. Int J Syst Bacteriol 43, 574-584.

Shooner, F., Bousquet, J. \& Tyagi, R. D. (1996). Isolation, phenotypic characterization, and phylogenetic position of a novel, facultatively autotrophic, moderately thermophilic bacterium, Thiobacillus thermosulfatus sp. nov. Int J Syst Bacteriol 46, 409-415.

Smibert, R. M. \& Krieg, N. R. (1981). General characterization. In Manual of Methods for General Microbiology, pp. 409-443. Edited by P. Gerhardt, R. G. E. Murray, R. N. Costilow, E. W. Nester, W. A. Wood, N. R. Krieg \& G. H. Phillips. Washington, DC: American Society for Microbiology.

Song, B., Young, L. Y. \& Palleroni, N. J. (1998). Identification of denitrifier strain $\mathrm{T} 1$ as Thauera aromatica and proposal for emendation of the genus Thauera definition. Int J Syst Bacteriol 48, 889-894.

Song, B., Häggblom, M. M., Zhou, J., Tiedje, J. M. \& Palleroni, N. J. (1999). Taxonomic characterization of denitrifying bacteria that degrade aromatic compounds and description of Azoarcus toluvorans sp. nov. and Azoarcus toluclasticus sp. nov. Int J Syst Bacteriol 49, $1129-1140$.
Song, B., Palleroni, N. J. \& Häggblom, M. M. (2000). Description of strain 3CB-1, a genomovar of Thauera aromatica, capable of degrading 3-chlorobenzoate coupled to nitrate reduction. Int J Syst Evol Microbiol 50, 551-558.

Song, B., Palleroni, N. J., Kerkhof, L. J. \& Häggblom, M. M. (2001). Characterization of halobenzoate-degrading, denitrifying Azoarcus and Thauera isolates and description of Thauera chlorobenzoica sp. nov. Int J Syst Evol Microbiol 51, 589-602.

Springer, N., Ludwig, W., Philipp, B. \& Schink, B. (1998). Azoarcus anaerobius sp. nov., a resorcinol-degrading, strictly anaerobic, denitrifying bacterium. Int J Syst Bacteriol 48, 953-956.

Stackebrandt, E. \& Goebel, B. M. (1994). Taxonomic note: a place for DNA-DNA reassociation and 16S rRNA sequence analysis in the present species definition in bacteriology. Int J Syst Bacteriol 44, 846-849.

Stöhr, R., Waberski, A., Liesack, W., Völker, H., Wehmeyer, U. \& Thomm, M. (2001). Hydrogenophilus hirschii sp. nov., a novel thermophilic hydrogen-oxidizing $\beta$-proteobacterium isolated from Yellowstone National Park. Int J Syst Evol Microbiol 51, 481-488.

Suzuki, K., Goodfellow, M. \& O'Donnell, A. G. (1993). Cell envelopes and classification. In Handbook of New Bacterial Systematics, pp. 195-250. Edited by M. Goodfellow \& A. G. O'Donnell. London: Academic Press.

Takeda, M., Kamagata, Y., Ghiorse, W. C., Hanada, S. \& Koizumi, J. (2002). Caldimonas manganoxidans gen. nov., sp nov., a poly(3hydroxybutyrate)-degrading, manganese-oxidizing thermophile. Int J Syst Evol Microbiol 52, 895-900.

Ward, D. M., Ferris, M. J., Nold, S. C. \& Bateson, M. M. (1998). A natural view of microbial biodiversity within hot spring cyanobacterial mat communities. Microbiol Mol Biol Rev 62, 1353-1370.

Wilkinson, S. G. (1988). Gram-negative bacteria. In Microbial Lipids, vol. I, p. 299-488. Edited by C. Ratledge \& S. G. Wilkinson. London: Academic Press. 